\title{
PENGUATAN KETERAMPILAN KONSELING ANAK: MEMAHAMI KARAKTERISTIK ANAK MELALUI PERMAINAN BALOGO
}

Dikirim tanggal 27 September 2017 Diterima tanggal 06 Oktober 2017 Dipublish tanggal 06 Oktober 2017

\author{
Mufida Istati \\ Fakultas Tarbiyah dan Keguruan , Program Studi Bimbingan Konseling Islam \\ UIN Antasari Banjarmasin \\ Email: mufidach@yahoo.co.id
}

\begin{abstract}
The aim of this study to know about Balogo game can help the counselor to understanding the children characteristics. This research is a qualitative study of literature study. In collecting the data, the writer used documentation. Data were analysis by Balogo game analysis from the theory psychology of childrent development by Nurihsan \& Agustin (2011) and the theory children counseling by Geldard \& Geldard (2012). The age of childrent in this research is 7-12 years old who get study in elementary school or Islamic elementary school. The children development characteristic can to know by the counselor through balogo game include the aspects of cognitive development, affective, physical-motor, moral, and religion. Counselors who understand the characteristics of children will support the achievement of child counseling success.
\end{abstract}

Key words: counseling, kareteristik child, balago

\section{ABSTRAK}

Penelitian ini bertujuan mengetahui tentang melalui permainan balogo dapat membantu konselor dalam memahami karakteristik anak. Penelitian ini merupakan penelitian kualitatif studi kepustakaan. Pengumpulan data dilakukan dengan dokumentasi. Analisis data dengan menganalisis permainan balogo ditinjau dari teori psikologi perkembangan anak oleh Nurihsan \& Agustin (2011) serta teori konseling anak oleh Geldard \& Geldard (2012). Anak yang mendapatkan layanan konseling dalam penelitian ini yaitu anak yang berada pada rentang usia 7-12 tahun yang sedang berada pada tingkat pendidikan Sekolah Dasar/Masdrasah Ibtidaiyah. Karakteristik perkembangan anak yang dapat diketahui oleh konselor melalui permainan balogo. Aspek pekembangan kognitif, afektif, fisik-motorik, moral, dan beragama. Konselor yang memahami karakteristik anak akan mendukung tercapainya keberhasilan konseling anak.

Kata Kunci: konseling, kareteristik anak, balago

\section{PENDAHULUAN}

Layanan bimbingan dan konseling diberikan kepada seluruh individu dari kalangan usia anak, remaja, dewasa, hingga lanjut usia. Konselor perlu memahami karakteristik setiap individu yang menjadi sasaran layanan bimbingan dan konseling. Agar keberhasilan layanan bimbingan dan konseling dapat tercapai secara optimal.

Tohirin $(2007,20)$ mendefinisikan bimbingan merupakan bantuan yang diberikan oleh pembimbing kepada individu agar individu yang dibimbing mencapai kemandirian. Dengan mempergunakan berbagai bahan, melalui interkasi, dan pemberian nasihat serta gagasan dalam suasana asuhan dan berdasarkan norma-norma yang berlaku. Sedangkan konseling didefinisikan Tohirin (2001: 25) merupakan kontak atau hubungan timbal balik antara dua orang (konselor dan konseli) untuk menangani masalah konseli. Bantuan 
tersebut didukung oleh keahlian dan dalam suasana yang laras dan integrasi berdasarkan norma-norma yang berlaku untuk tujuan yang berguna bagi konseli.

Setiap individu yang mendapatkan layanan bimbingan dan konseling memiliki karakteristik yang berbeda. Upaya konselor dan guru dalam memahami karakteristik individu dapat diklasifikasikan berdasarkan perkembangan psikologi pada masa usia dari anak, remaja, dewasa, dan lanjut usia.

Elfi Mu'awanah dan Rifa Hidayah (2012), melaporkan hasil survei problematik pribadi dan sosial peserta didik di sekolah dasar. Secara umum temuan penelitian terdapat kecenderungan perilaku negatif siswa meliputi: meminta uang kepada temannya, selalu usil kepada teman, mudah tersinggung dan menangis, kadang bicara yang tidak sopan, bertengkar sesama teman, jajan sembarangan, tidak mau mengalah atau menang sendiri. Tindakan penanganan yang harus dilakukan oleh guru adalah seperti menasihati, memberi pembinaan hidup mandiri, tukar pendapat dengan orang tua, dan memberikan bimbingan (Irham \& Wiyani, 2014: 147).

Berdasarkan laporan hasil penelitian tersebut maka diperlukan peran guru dan konselor anak. Konselor anak diharapkan dapat membantu anak untuk mengubah perilaku negatifnya menjadi perilaku positif. Sebagai upaya menjadi seorang konselor anak dibutuhkan pemahaman yang mendalam tentang karakteristik psikologi perkembangan anak.

Konselor diharapkan mampu memahami karakteristik perkembangan anak ketika memberikan layanan bimbingan dan konseling untuk anak pada rentang usia 7-12 tahun yang sedang berada pada tingkat pendidikan sekolah dasar/ masdrasah ibtidaiyah. Karakteristik perkembangan anak ditinjau dari psikologis meliputi aspek perkembangan kognitif, afektif, dan fisik-motorik, moral, dan beragama anak.

Salah satu cara untuk memahami karakteristik anak adalah dengan melalui permainan. Ketika anak melaksanakan aktivitas bermain, seluruh aspek fisik dan psikologisnya mendapat stimulasi, sehingga akan memunculkan respon dari anak.

Jenis permainan yang diterapkan juga harus memenuhi fungsi-fungsi bermain bagi anak. Permainan tradisional kalimantan selatan khususnya "Balogo" dapat dikategorikan permainan yang memenuhi fungsi bermain bagi anak. Fungsi bermain bagi anak menurut Musfiroh (2008) dalam Suwarjo \& Eliasa (2010: 8) meliputi (1) fungsi perkembangan kemampuan intelektual yaitu dapat menstimulus perkembangan kognitif, membangun struktur kognitif, membangun kemampuan kognitif, memecahkan masalah, dan mengembangkan rentang konsentrasi, (2) fungsi perkembangan bahasa anak, (3) fungsi perkembangan sosial yaitu dapat meningkatkan sikap sosial, belajar berkomunikasi, belajar berorganisasi, (4) fungsi perkembangan emosi mencakup kstabilan emosi, rasa kompetensi dan percaya diri, menyalurkan energi fisik yang terpendam.

\section{METODE PENELITIAN}

Penelitian ini merupakan penelitian kualitatif studi kepustakaan. Pengumpulan data dilakukan dengan dokumentasi. Analisis data dilakukan dengan menganalisis permainan balogo ditinjau dari teori pelaksanaan konseling anak. Dalam buku Geldard, K \& Geldard, D (2012) Konseling Anak-anak Sebuah Pengantar Praktis Edisi Ketiga terjemahan oleh Gianto Widijanto \& Lilian Yuwono. Permainan balogo dapat membantu meningkatkan keterampilan konselor dalam memahami karakteristik anak. 


\section{HASIL DAN PEMBAHASAN}

1. Hubungan Konselor-Anak

Keterampilan konseling anak harus relevan untuk tahap proses konseling. Secara umum proses konseling terdiri atas serangkaian sesi, di mana konselor harus melakukan peran dan fungsi konselor yang berbeda-beda. Ada tujuh keterampilan konseling anak yang perlu dikuasai oleh konselor anak. Keterampilan konseling anak tersebut meliputi (1) menjalin hubungan yang efektif dengan anak, (2) mengobservasi anak, (3) mendengarkan secara aktif, (4) meningkatkan kesadaran dan pemecahan masalah untuk memfasilitasi perubahan, (5) menangani konsep diri anak dan kepercayaan yang merusak diri, (6) secara aktif memfasilitasi perubahan,dan (7) mengakhiri (Geldard, K \& David.Geldard, D, 2012: 125-126).

Berdasarkan penjelasan Geldard, K \& David Geldard, D (2012: 125-126) tentang ada 7 keterampilan yang harus dimiliki oleh seorang konselor dalam melaksanakan konseling anak, maka proses yang dibutuhkan oleh konselor anak agar dapat menguasai 7 keterampilan tersebut diperlukan cara yang tepat dan sesuai untuk memahami karakteristik anak.

Eisenberg \& Delaney (1977: 5-10) dalam Mappiare (2010: 123) mengemukakan bahwa, salah satu ciri khusus kemampuan konselor yang efektif yaitu yaitu para konselor (helper) yang efektif berusaha memahami, bukannya menghakimi tingkah laku orang yang diupayakan untuk dibantu. Sepertinya sudah merupakan kecenderungan kuat manusia untuk menetapkan patokanpatokan bagi tingkah laku orang lain. Konselor yang efektif berusaha keras mengontrol kecenderungan ini pada dirinya. Mereka justru menerima pola tingkah laku yang dihadapinya sebagai bagian dari cara seseorang menangai hidup dan mereka mencoba memahami bagaimana sampai berkembang pola demikian, dan mengapa orang yang diupayakan di bantu bertinglaku demikian. Konselor yang efektif memiliki pemahaman yang berkembang tentang tingkah laku manusia. Maka seorang konselor anak yang efektif diharapkan memiliki pemahaman pada anak yang menerima layanan bimbingan dan konseling.

Karakteristik anak yang perlu dipahami oleh konselor anak untuk mewujudkan penguasaan keterampilan konseling anak mencakup beberapa aspek perkembangan. Konselor diharapkan dapat memahami aspek perkembangan kognitif, afektif, fisik \& motorik, moral dan beragama anak.

2. Karakteristik Perkembangan Anak

Anak usia Sekolah Dasar/Madrasah Ibtidiyah berada pada usia antara 7-12 tahun. Kaakteristik perkembangan anak dapat ditinjau dari beberapa aspek meliputi kognitif, fisik-motorik, serta moral dan keagamaan.

a.Perkembangan kognitif

Aspek perkembangan kognitif anak meliputi kemampuan berpikir, persepsi, bahasa, dan bicara. Menurut Zulkifli (2009: 58) berpikir terkandung perbuatan menimbang-nimbang, menguraikan, menghubung-hubungkan, sampai akhirnya mengambil keputusan. Kecerdasan terkandung tingkat kemampuan seorang dalam memecahkan masalahnya.

Dalam keadaan pertumbuhan yang biasa, pikiran berkembang secara berangsur-angsur, sampai anak mencapai umur 8-12 tahun. Ingatan anak menjadi kuat sekali. Biasanya mereka suka menghafal.

Minat anak ditujukan kepada benda-benda yang bergerak. Anak yang sehat pertumbuhannya suka bergerak, selalu giat, dan berbuat sesuatu. Hal-hal yang mengandung kegiatan selalu menarik perhatiannya. Anak harus 
banyak diberi kesempatan untuk berbuat, bergerak, dan bertindak. Bila "kegiatan" ini kurang mendapat penyaluran atau bimbingan yang baik, maka besar kemungkinan anak hanya bertindak dengan asal berbuat saja. (Zulkifli, 2009: 59)

Dalam perkembangan kognitif juga terdapat aspek persepsi. Menurut Desmita (2012: 118) persepsi adalah suatu proses penggunaan pengetahuan yang telah dimiliki untuk memperoleh dan menginterpretasi stimulus yang diterima oleh sistem alat indra manusia. Jadi, persepsi pada dasarnya menyangkut hubungan manusia dengan lingkungannya, bagaimana ia mengerti dan menginterpretasikan stimulus yang ada di lingkungannya dengan menggunakan pengetahuan yang dimilikinya. Setelah individu mengindrakan objek di lingkungannya, kemudian ia memproses hasil pengindraannya itu, sehingga timbulah makna tentang objek tersebut.

Dalam Nurihsan \& Agustin (2011) bahasa dapat berbentuk lisan atau tulisan dengan mempergunakan tanda (coding), huruf (alphabetic), bilangan (numerical), bunyi, sinar atau cahaya yang dapat merupakan kata-kata (words) atau kalimat. Mungkin pula berbentuk gambar atau lukisan, gerak-gerik, dan mimik serta bentuk-bentuk simbol ekspresif lainnya.

Pada masa anak sekolah dengan dikuasainya keterampilan membaca dan berkomunikasi dengan orang lain, maka pada periode 6-8 tahun, ia dengan senang hati membaca atau mendengar dongeng fantasi; usia 10-12 tahun gemar (dengan) cerita yang bersifat kritis (tentang perjalanan, riwayat para pahlawan dan sebagainya).

b. Perkembangan afektif

Aspek afektif meliputi dimensi emosi dan penyesuaian sosial. Nurihsan \& Agustin (2011) mengemukakan dimensi emosional yang sangat penting diketahui (oleh) para guru ialah (1) senang tidak senang atau suka tidak suka dan (2) intensitas dalama term kuatlemah atau halus-kasarnya atau dalamdangkalnya emosi tersebut. Hal-hal itu penting karena dapat memberikan motivasi pengarahan dan integritas perilaku seseorang.

Penyesuaian sosial anak terkait perkembangan perilaku sosial anak ditandai dengan adanya minat terhadap aktivitas teman-teman dan meningkatnya keinginan yang kuat untuk diterima sebagai suatu kelompok, dan merasa tidak puas bila tidak bersama temantemannya. Anak tidak lagi puas bermain sendiri di rumah atau dengan saudarasaudara kandung atau melakukan kegiatan dengan anggota-anggota keluarga (Nurihsan \& Agustin, 2011).

c. Perkembangan fisik-motorik

Perkembangan fisik anak terkait erat dengan perilaku motoriknya. Perilaku motorik memerlukan adanya koordinasi fungsional antara neuromuscular system (persyarafan dan otot) dan fungsi psikis (kognitif, afektif, dan konatif). Menurut Loree (1970: 75) menyatakan bahwa ada dua macam perilaku psikomotorik utama yang bersifat universal harus dikuasai oleh individu pada masa bayi atau awal masa anak-anak, ialah: berjalan dan memegang benda. Kedua jenis keterampilan psikomotorik yang lebih kompleks seperti yang kita kenal dengan sebutan bermain dan bekerja.

Dua prinsip perkembangan utama yang tampak dalam semua perilaku psikomotorik ialah (1) bahwa perkembangan itu berlangsung dari yang sederhana kepada yang kompleks, dan (2) dari yang kasar dan global kepada yang halus dan spesifik tetapi terkoordinasi (Nurihsan \& Agustin: 2011, 26-27).

Usaha untuk memperhalus keterampilan motorik anak-anak terus melakukan berbagai aktivitas fisik. Aktivitas fisik ini dilakukan dalam bentuk permainan yang kadang-kadang 
bersifat informal, permainan yang diatur sendiri oleh anak.

Anak-anak masa sekolah mengembangkan kemampuan melakukan permainan dengan peraturan, sebab mereka sudah dapat memahami dan menaati aturan-aturan suatu permainan, pada waktu yang sama, anakanak mengalami peningkatan dalam koordinasi dan pemilihan waktu yang tepat dalam melakukan berbagai cabang olahraga baik secara individual maupun kelompok (Mubin \& Cahyadi, 2006: 9293).

d. Perkembangan moral dan keagamaan anak

Sebagai makhluk ciptaan Tuhan, sebenarnya potensi agama sudah ada pada setiap manusia sejak dia dilahirkan. Potensi ini berupa dorongan untuk mengabdi kepada Sang Pencipta. Dalam terminologi Islam dorongan ini dikenal dengan hidayat al-Diniyyat (baca: hidayatud diniyyah), berupa benih-benih keberagamaan yang dianugerahkan Tuhan kepada manusia.

Manusia merupakan makhluk beragama. Anak-anak memerlukan tuntunan dan bimbingan, sejalan dengan tahap perkembangan yang mereka alami. Tokoh yang paling menentukan dalam menumbuhkan rasa keberagamaan itu adalah orang tuanya.

Nabi Muhammad Saw. Bersabda: "Perintahlah anak-anak kalian melakukan shalat ketika ia berusia tujuh tahun, dan pukullah ia jika meninggalkannya apabila berusia sepuluh tahun, dan pisahkan ranjangnya: (HR. Ahmad, Abu Daud dan al-Hakim dalam Mubin \& Cahyadi, 2006: 102).

Hadits di atas mengisyaratkan bahwa usia tujuh tahun merupakan usia mulai berkembangnya kesadaran akan perbuatan baik dan buruk, benar dan salah. Sehingga Nabi Muhammad Saw. Memerintahkan kepada orang tua untuk mendidik shalat kepada anak-anaknya.
Ketika usia sepuluh tahun, tingkat kesadaran anak akan perbuatan baik dan buruk, benar dan salah mendekati sempurna sehingga Nabi Muhammad Saw memerintahkan orang tua memukul anaknya yang meninggalkan shalat. Makna "memukul" di sini mengarah pada psikologis seperti menggugah kesadaran anak (Mubin \& Cahyadi, 2006: 102).

3. Permainan Tradisional Kalimantan Selatan

Jenis-jenis permainan yang dapat membantu konselor untuk memahami karakteristik anak pada aspek kognitif, afektif, fisik \& motorik, moral dan beragama anak.

Traditional Game atau permainan tradisional merupakan unsur-unsur kebudayaan yang tidak dapat dianggap remeh, karena permainan tradisional memberikan pengaruh yang besar terhadap perkembangan kejiwaan, sifat, dan kehidupan sosial anak dikemudian hari. Bermain secara umum sering dikaitkan dengan kegiatan anak-anak yang dilakukan secara spontan, dimana terdapat empat unsur dalam bermain, yaitu: Sesuatu yang menyenangkan dan memiliki nilai intrinsik, Tidak memiliki tujuan ekstrinsik, motivasinya lebih bersifat intrinsik. Bersifat spontan dan sukarela, tidak ada unsur keterpaksaan dan bebas dipilih oleh anak serta melibatkan peran aktif keikutsertaan anak, Memiliki hubungan sistematik yang khusus dengan sesuatu yang bukan bermain, seperti kreativitas, pemecahan masalah, belajar bahasa dan perkembangan sosial.

Permainan tradisional juga dikenal sebagai permainan rakyat, merupakan sebuah kegiatan rekreatif yang tidak hanya bertujuan untuk menghibur diri, tetapi juga sebagai alat untuk memelihara hubungan dan kenyamanan sosial (Hapsari, 2012: 5). 
Permainan "Balogo" merupakan salah satu jenis permainan tradisional suku Banjar di Kalimantan Selatan. Hapsari (2012: 5) menjelaskan tentang permainan "Balogo". "Balogo" diambil dari kata "logo", karena permainan itu menggunakan "logo". Sampai dengan tahun 80-an permainan ini masih sering dilakukan di kalangan masyarakat Banjar. Namun, dewasa ini sudah mulai tersisih oleh permainan elektronik. Perminan Balogo lebih sering dimainkan oleh anak laki-laki

Peralatan yang digunakan dalam permainanan Balogo meliputi Logo dan Panapak. "Logo" terbuat dari tempurung kelapa. Garis tengahnya sekitar $5-7 \mathrm{~cm}$ dan tebalnya sekitar 1-2 cm. Kebanyakan dibuat berlapis dua yang direkatkan dengan bahan aspal atau dempul supaya berat dan kuat. Bentuknya bermacammacam, ada yang berbentuk bidawang (bulus), biuku (penyu), segi tiga, layanglayang, daun dan bundar.

Dalam permainan harus dibantu dengan sebuah alat yang disebut panapak atau kadang-kadang beberapa daerah ada yang menyebutnya campai, yakni stik atau alat pemukul yang panjangnya sekitar $40 \mathrm{~cm}$ dengan lebar $2 \mathrm{~cm}$. Fungsi panapak atau campai adalah untuk mendorong "logo" agar bisa meluncur dan merobohkan "logo" yang dipasang saat bermain.

\section{Tabel 1}

Peralatan Bermain Balogo (Hapsari, 2012: 12)

\begin{tabular}{|c|c|c|}
\hline $\begin{array}{l}\mathrm{N} \\
\mathrm{O}\end{array}$ & Gambar alat & Keterangan \\
\hline 1. & & $\begin{array}{l}\text { Logo, Game } \\
\text { Object utama } \\
\text { yang dimainkan } \\
\text { dalam game } \\
\text { "Balogo }\end{array}$ \\
\hline 2. & & $\begin{array}{l}\text { Panapak, adalah } \\
\text { alat utama yang } \\
\text { digunakan untuk } \\
\text { memukul logo }\end{array}$ \\
\hline
\end{tabular}

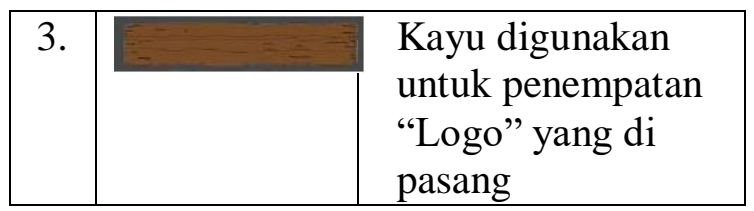

Aturan dan proses permainan Balogo (yaitu) pemain diharuskan merobohkan atau menjatuhkan "logo" yang sudah dipasang. Cara memasang "logo" adalah dengan mendirikannya secara berderet ke belakang pada garisgaris melintang. Inti dari permainan ini adalah keterampilan memainkan "logo" agar bisa merobohkan "logo" yang dipasang.

3. Memahami Karakteristik Anak Melalui Permainan Tradisional Kalimantan Selatan

1) Perkembangan Kognitif

Perkembangan kognitif anak yang dapat diamati dari pelaksanaan permainan Balogo meliputi kemampuan berpikir, persepsi, serta bicara dan bahasa.

Kemampuan anak dalam berpikir dapat diamati dari pemahaman anak terhadap aturan main dan cara bermain balogo. Anak meletakkan alat main yaitu, panapak, dan kayu sesuai dengan tempatnya. Anak memiliki strategi agar dapat merobohkan atau menjatuhkan "logo" yang sudah dipasang. Cara memasang "logo" adalah dengan mendirikannya secara berderet ke belakang pada garis-garis melintang. Inti dari permainan ini adalah keterampilan memainkan "logo" agar bisa merobohkan "logo" yang dipasang.

Kemampuan persepsi anak dapat diamati ketika anak peka menginterpreasi hasil penginderaaan. Misalnya, anak dengan menggunakan inderanya dapat memahami karakteristik peralatan main balogo. Sehingga dapat menyesuaikan cara memainkannya jika logo terbuat dari tempurung kelapa atau aspal.

Aspek perkembangan bahasa dan bicara dapat diketahui dari penerapan bahasa yang digunakan ketika anak 
berbicara. Anak memiliki kemampuan berbahasa yang baik jika mampu berbahasa yang baik dan jelas. Sehingga teman-temannya dapat memahami pesan yang ingin disampaikannya.

2) Perkembangan Afektif

Aspek perkembangan afektif anak yang dapat diamati mencakup emosi dan penyesuaian sosial. Kemampuan mengelola emosi dapat diamati ketika anak bermain. Anak yang mampu mengelola emosi dengan baik akan berusaha menjaga perasaan temannya. Anak tidak mengekspresikan emosi negatif yang dapat menyakiti perasaan maupun fisik dirinya sendiri dan orang lain.

Kemampuan penyesuaian sosial anak dapat diketahui ketika anak dapat menyesuaikan diri dengan lingkungan bermain dan teman-temannya. Anak dapat berkomunikasi dengan baik secara verbal dan non verbal.

3) Perkembangan Fisik-Motorik

Perkembangan fisik-motorik meliputi kondisi fisik dan aktivitas motorik anak ketika bermain Balogo. Anak yang memiliki perkembangan fisik yang baik dapat diketahui dari kemampuan anak menggunakan anggota badannya untuk bermain balogo. Anak meletakkan alat main yaitu, panapak, dan kayu sesuai dengan tempatnya.

Anak mampu memasang "logo"dengan mendirikannya secara berderet ke belakang pada garis-garis melintang. Anak memiliki keterampilan memainkan "logo" agar bisa merobohkan "logo" yang dipasang.

4) Perkembangan Moral dan Keagamaan Perkembangan moral dan keagamaan anak. Anak yang bermain secara sehat atau tidak melakukan kecurangan dapat dimaknai anak tersebut memiliki kesadaran moral yang baik. Artinya anak mampu membedakan tentang perilaku yang benar dan salah.
Perilaku bermain yang akan merugikan dirinya sendiri maupun orang lain akan dihindarinya. Misalnya, perilaku sengaja mengganggu teman yang sedang menggunakan panapak untuk merobohkan logo. Sehingga menyebabkan temannya terjatuh menunjukkan (bahwa) anak belum memiliki kesadaran moral yang baik.

Contoh format observasi bagi konselor/guru BK/guru SD/MI untuk memahami karakteristik perkembangan anak melalui permainan Balogo sebagai berikut.

Tabel 2. Format Observasi Bagi Guru BK/Konselor Anak

\begin{tabular}{|c|c|c|c|c|c|c|}
\hline \multirow{2}{*}{ No } & \multirow{2}{*}{$\begin{array}{c}\text { Aspek } \\
\text { perkembangan }\end{array}$} & \multirow{2}{*}{ Komponen } & \multicolumn{4}{|c|}{ skor } \\
\hline & & & 1 & 2 & 3 & 4 \\
\hline \multirow[t]{6}{*}{1.} & Kognitif & & & & & \\
\hline & $\begin{array}{l}\text { a. Kemampua } \\
\text { n berpikir }\end{array}$ & $\begin{array}{l}\text { Memahami tata } \\
\text { cara bermain }\end{array}$ & & & & \\
\hline & & $\begin{array}{l}\text { Memiliki } \\
\text { strategi agar } \\
\text { dapat bermain } \\
\text { dengan baik }\end{array}$ & & & & \\
\hline & b. Persepsi & $\begin{array}{l}\text { Memiliki } \\
\text { kepekaan } \\
\text { menginterpreta } \\
\text { si hasil } \\
\text { penginderaaan }\end{array}$ & & & & \\
\hline & c. Bicara & $\begin{array}{l}\text { Pengucapan } \\
\text { pesan yang } \\
\text { disampaikan } \\
\text { secara lisan }\end{array}$ & & & & \\
\hline & & $\begin{array}{l}\text { Penerapan } \\
\text { bahasa yang } \\
\text { digunakan } \\
\text { ketika } \\
\text { berbicara }\end{array}$ & & & & \\
\hline \multirow[t]{3}{*}{2.} & Afektif & & & & & \\
\hline & Emosi & $\begin{array}{l}\text { Aktivitas } \\
\text { mengekspresik } \\
\text { an perasaan }\end{array}$ & & & & \\
\hline & $\begin{array}{l}\text { Penyesuaian } \\
\text { sosial }\end{array}$ & $\begin{array}{l}\text { Interaksi sosial } \\
\text { dengan teman }\end{array}$ & & & & \\
\hline \multirow[t]{3}{*}{3.} & Fisik-Motorik & & & & & \\
\hline & Fisik & $\begin{array}{l}\text { Memiliki } \\
\text { anggota tubuh } \\
\text { yang normal }\end{array}$ & & & & \\
\hline & Motorik & $\begin{array}{l}\text { Mampu } \\
\text { melakukan } \\
\text { gerakan } \\
\text { aktivitas fisik }\end{array}$ & & & & \\
\hline
\end{tabular}




\begin{tabular}{|l|l|l|l|l|l|l|}
\hline 4 & $\begin{array}{l}\text { Moral dan } \\
\text { beragama }\end{array}$ & & & & \\
\hline & Moral & $\begin{array}{l}\text { Mematuhi } \\
\text { aturan main }\end{array}$ & & & & \\
\hline & Keagamaan & $\begin{array}{l}\text { Aktivitas } \\
\text { berdoa }\end{array}$ & & & & \\
\hline
\end{tabular}

Ket: 1=tidak baik, 2=kurang baik, 3=baik, 4=sangat baik

Secara umum kriteria pengklasifikasian tingkat perkembangan psikologis anak dapat diketahui berdasarkan rentang skala berikut.

\begin{tabular}{|c|c|}
\hline Rentang Skor & Kategori \\
\hline $36-44$ & Sangat baik \\
\hline $28-35$ & Baik \\
\hline $19-27$ & Kurang baik \\
\hline $11-18$ & Tidak baik \\
\hline
\end{tabular}

\section{PENUTUP}

\section{Kesimpulan}

Aspek yang perlu diperhatikan dalam melaksanakan peran sebagai konselor anak adalah memahami karakteristik perkembangan psikologi anak. Agar keberhasilan tujuan layanan bimbingan dan konseling untuk anak dapat tercapai.

Salah satu cara untuk memahami karakteristik anak adalah dengan melalui permainan. Ketika anak melaksanakan aktivitas bermain seluruh aspek fisik dan psikologisnya mendapat stimulasi. Sehingga akan memunculkan respon dari anak.

Jenis permainan yang diterapkan juga harus memenuhi fungsi-fungsi bermain bagi anak. Permainan tradisional kalimantan selatan khususnya "Balogo" dapat dikategorikan permainan yang memenuhi fungsi bermain bagi anak. Fungsi bermain bagi anak menurut Musfiroh (2008) dalam Suwarjo \& Eliasa (2010: 8) meliputi (1) fungsi perkembangan kemampuan intelektual (2) fungsi perkembangan bahasa anak, (3) fungsi perkembangan sosial, (4) fungsi perkembangan emosi.

Penerapan permainan tradisional Kalimantan Selatan dapat diterapkan berdasarkan minat anak terhadap permainan. $\begin{array}{ccc}\text { Beberapa } & \text { aspek yang perlu } \\ \text { diperhatikan } & \text { dalam memahami } \\ \text { karakteristik } & \text { perkembangan psikologi }\end{array}$ anak melalui permainan Balogo meliputi: (1) kognitif terdiri dari pengamatan pada komponen (a) kemampuan berpikir anak (memahami tata cara bermain, memiliki strategi agar dapat bermain dengan baik), (b) Persepsi (memiliki kepekaan menginterpretasi hasil penginderaaan), (c) bicara dan bahasa (pengucapan pesan yang disampaikan secara lisan, penerapan bahasa yang digunakan ketika berbicara), (2) afektif terdiri dari (a) kemampuan mengelola Emosi (cara mengekspresikan perasaan), (b) penyesuaian sosial, (3) aspek fisikmotorik, terdiri dari (a) memiliki anggota tubuh yang normal, (b) mampu melakukan gerakan aktivitas fisik ketika bermain, (4) aspek moral dan beragama terdiri dari (a) mematuhi aturan bermain (b) aktivitas berdoa.

\section{Saran}

Bagi pelaksana layanan bimbingan dan konseling untuk anak di Sekolah Dasar/Madrasah Ibtidaiyah dapat menerapkan permainan tradisional kalimantan selatan yaitu Balogo Dengan memahami karakteristik anak akan membantu konselor menjalin hubungan yang baik. Konselor memahami potensi yang dimiliki anak untuk mencapai tujuan layanan bimbingan dan konseling.

\section{DAFTAR PUSTAKA}

Desmita. 2012. Psikologi Perkembangan

Peserta Didik Panduan bagi

Orang Tua dan Guru dalam

Memahami Psikologi Anak Usia

$S D, S M P$, dan SMA. Bandung:

Remaja Rosdakarya.

Geldard, K \& Geldard, D. 2012.

Konseling Anak-anak Sebuah

Pengantar Praktis Edisi Ketiga.

Terjemahan oleh Gianto 
Widijanto \& Lilian Yuwono. Jakarta: Indeks.

Hapsari, T. 2012. Perancangan Game Taradisional dari Kalimantan "Balogo" dengan Menggunakan UNITY. Naskah Publikasi. Jurusan Teknik Informatika STIMIK AMIKOM Yogyakarta.

Irham, M. \& Wiyani, N., A. 2014.

Bimbingan dan Konseling Teori dan Aplikasi di Sekolah Dasar. Yogyakarta: Ar-Ruzz Media. Mappiare AT, Andi. 2010. Pengantar Konseling dan Psikoterapi. Jakarta: Rajagrafindo Persada. Mubin \& Ani Cahyadi. 2006. Psikologi

Perkembangan. Ciputat: Quantum Teaching

Nurihsan, A., J. \& Agustin, M. 2011.

Dinamika Perkembangan Anak dan Remaja: Tinjauan Psikologi, Pendidikan, dan Bimbingan.

Bandung: Refika Aditama.

Tohirin. 2007. Bimbingan dan

Konseling di Sekolah dan Madrasah (Berbasis Integrasi).

Jakarta: Rajagrafindo Persada.

Zulkifli L. 2009. Psikologi

Perkembangan. Bandung:

Remaja Rosdakarya. 